\title{
O USO DA LEGISLAÇÃO EDUCACIONAL COMO FONTE: orientações a partir do marxismo ${ }^{1}$
}

\author{
André Paulo Castanha ${ }^{2}$
}

\begin{abstract}
RESUMO:
O objetivo principal do texto é apresentar algumas alternativas teóricas e metodológicas para o uso e interpretação da legislação educacional como fonte nos estudos históricoeducativos. Como utilizá-las? Como interpretá-las? Eis algumas questões que norteiam o estudo. As leis da educação são apresentadas como sínteses de múltiplas determinações, visto que expressam projetos políticos e de civilização carregados de sonhos, desejos, direitos, deveres, preconceitos, interesses públicos e privados, enfim trazem em si as contradições presentes na sociedade. As leis são, portanto, documentos fundamentais para compreender o processo histórico de um determinado período. As reflexões estão fundamentadas no marxismo com ênfase nas contribuições de Marx, Gramsci, Thompson e Ragazzini.

Palavras chaves: Legislação educacional, Interpretação de fontes, Marxismo, História da Educação
\end{abstract}

\section{THE USE OF LEGISLATION AS AN EDUCATIONAL SOURCE: orientation from the Marxism}

\begin{abstract}
:
This text aims to present some theoretical and methodological alternatives for the use and interpretation of educational legislation as a source in historical educative studies. How to use them? How to interpret them? Here are some questions that guide the study. The education laws are presented as the synthesis of multiple deteremination, as they express politic and civilization projects loaded with dreams, wishes, rights, duties, private and public interests, at all they bring inner selves the contradictions presented in the society. The law are, therefore, fundamental documents for understanding the historical process of a certain period. The reflections are fundamental in the Marxism with emphasis in Marx, Gramsci, Thompson and Ragazzini contributions.

Keywords: Educational legislation, Source Interpretation, Marxism, History of Education.
\end{abstract}

O processo de desenvolvimento histórico é uma unidade no tempo pelo que o presente contém todo o passado e do passado se realiza no presente o que é "essencial", sem resíduo de um "incognoscível" que seria a verdadeira “essência". O que se "perdeu", isto é, o que não foi transmitido dialeticamente no processo histórico, era por si mesmo irrelevante, era "escória" casual e contingente, crônica e não história, episódio superficial, sem importância, em última análise. (GRAMSCI, 2004, p. 240). 
Nas últimas duas décadas, as pesquisas em história da educação tiveram uma grande difusão, devido à ampliação e consolidação dos programas de pós-graduação em educação e ao nascimento de vários grupos de pesquisa voltados ao campo históricoeducativo. Novos temas e objetos vêm sendo estudados pela perspectiva histórica, tais como: instituições escolares, ideias pedagógicas, processos de leitura, trabalho docente e formação de professores, cultura escolar, didática e métodos de ensino, manuais didáticos e livros de leitura, políticas educacionais, entre outros. A incorporação dessa variedade de objetos enriqueceu significativamente a história da educação, frente aos demais campos da educação. Se, por um lado, tivemos a inclusão de novos objetos, por outro, evidenciou-se certo abandono dos estudos clássicos da educação, como, por exemplo, a legislação educacional e a administração da educação.

As inovações teórico-metodológicas no campo da história, advindas com a emergência da História Nova e sua posterior fragmentação em história das mentalidades, do imaginário, do cotidiano, cultural, micro-história etc. foram incorporadas por um conjunto significativo de historiadores da educação. Todavia, tal incorporação se deu, em muitos casos, por modismo, e, em consequência disso, os conceitos das referidas correntes historiográficas foram apropriados de forma superficial, resultando em estudos subjetivos, sem articulação entre o particular e o geral e apresentando fragilidade no uso e interpretação das fontes.

Conforme destacado por Julio Aróstegui, a pesquisa histórica surge de "achados", desenvolve-se com a utilização de novas fontes, de novas conexões entre elas, de comparações, releituras, ou de inquietações com os acontecimentos ou explicações existentes, insatisfações que, por sua vez, são provocadas pelo aparecimento de novos pontos de vista, de novas "teorias", ou de novas formas de trabalhar com a documentação. Daí a necessidade de o historiador se preocupar com o modo como articular sua pesquisa, levando em consideração as fontes, a organização das informações, a tipologia e seu uso, assim como a relação com outras pesquisas da mesma área, ou similares. Segundo Aróstegui, a "prática da pesquisa histórica tem de ajustar-se à definição clara de problemas, à formulação de hipóteses, à construção de mecanismos para 'provar' comparativamente a adequação de suas explicações" (2006, p. 468-70). Tentei levar em conta essas recomendações, quando me propus a escrever a história da educação imperial sob uma nova perspectiva.

Ao estudar a educação imperial, cerquei-me de fontes do século XIX e, em especial, da legislação educacional. Ao fazer um estudo comparativo envolvendo quatro unidades administrativas foi possível me contrapor à tese da fragmentação e anarquia, ideia hegemônica entre os historiadores do período. O retorno às fontes da época, aliado a uma metodologia adequada de uso e interpretação da documentação permitiu rever e contestar várias afirmações cristalizadas pela historiografia educacional.

Os estudos envolvendo a legislação educacional em sua perspectiva histórica vêm sendo relegados ao segundo plano, em virtude das inovações introduzidas na historiografia. A legislação passou a ser objeto de análise, mais dos estudiosos que se debruçam sobre as políticas educacionais, do que dos historiadores. Ciente da importância da legislação como fonte histórica, tenho como principal objetivo, no presente texto, desenvolver algumas reflexões visando apontar alternativas teóricas e metodológicas para o uso e interpretação das leis da educação na perspectiva do marxismo. Os marxistas que servem de base a este estudo são: o próprio Marx, Gramsci, Thompson e Ragazzini.

O texto está organizado da seguinte forma: inicio com uma discussão sobre as fontes e a pesquisa em história da educação, destacando conceitos e tipos de fontes; em seguida, faço uma breve abordagem sobre leis e legislação; posteriormente, apresento a lei 
como síntese de múltiplas determinações, ou seja, como construção social e espaço de contradição e lutas sociais; por fim, analiso a legislação como fonte histórico-educativa apresentando sugestões metodológicas de uso e interpretação da legislação.

\section{As Fontes e a Pesquisa Histórico-Educativa}

O termo fonte vem do latim - fons, -tis, cujo sentido próprio remete a fonte, nascente e no seu sentido figurado, caracteriza-se como origem, causa, princípio. Já o dicionário Aurélio complementa, indicando como "aquilo que origina ou produz"; traz ainda o sentido de "procedência, proveniência" (FARIA, 1992, p, 228; FERREIRA, 2004, p. 920). Do sentido originário da palavra fonte emergiu o conceito de fonte histórica, cujo termo clássico para sua designação é documento, mas, atualmente, também são empregadas as palavras registros, vestígios. Todos estes termos são sinônimos que caracterizam tudo aquilo que foi e é "produzido pela humanidade no tempo e no espaço; a herança material e imaterial deixada pelos antepassados que serve de base para a construção do conhecimento histórico" (SILVA, 2005, p. 158).

$\mathrm{Na}$ atualidade, não há discórdia entre os historiadores de que as fontes ou documentos são os componentes indispensáveis para a sistematização do conhecimento histórico. O que diferencia os estudos é a forma de identificação, uso e interpretação. As fontes não falam por si, como afirmam os positivistas, mas são, de fato, os vestígios, as testemunhas que manifestam as ações do homem no tempo, por isso respondem como podem por um número limitado de fatos. Conforme assinalou Dermeval Saviani:

As fontes estão na origem, constituem o ponto de partida, a base, o ponto de apoio da construção historiográfica que é a reconstrução, no plano do conhecimento, do objeto histórico estudado. Assim, as fontes históricas não são a fonte da história, ou seja, não é delas que brota e flui a história. Elas, enquanto registros, enquanto testemunhos dos atos históricos, são a fonte do nosso conhecimento histórico, isto é, é delas que brota, e nelas que se apóia o conhecimento que produzimos a respeito da história (2004, p. 5-6).

José Claudinei Lombardi complementou:

As fontes resultam da ação histórica do homem e, mesmo que não tenham sido produzidas com a intencionalidade de registrar a sua vida e o seu mundo, acabam testemunhando o mundo dos homens em suas relações com outros homens e com o mundo circundante, a natureza, de forma que produza e reproduza as condições de existência e de vida (2004, p. 155).

Cabe, portanto, ao pesquisador a tarefa de localizá-las, selecioná-las e interrogá-las, pois, como indicou Dario Ragazzini "a fonte é o único contato possível com o passado que permite formas de verificação". O sucesso da empreitada vai depender da qualidade das perguntas que forem feitas aos documentos ou da forma como eles forem usados. Ragazzini enfatizou:

A fonte provém do passado, é o passado, mas não está mais no passado quando é interrogada. A fonte é uma ponte, um veículo, uma testemunha, um lugar de verificação, um elemento capaz de propiciar conhecimentos acertados sobre o passado (2001, p. 14).

Assim, devemos aceitar que não é possível compreender o passado em plenitude, 
por isso, sempre é bom lembrar que são as pesquisas, ou os pesquisadores que selecionam as suas fontes por razões temáticas ou de métodos.

O conceito, o uso e a interpretação das fontes históricas também são resultado das contradições sociais e, portanto, construído historicamente. Até as primeiras décadas do século XX, consideravam-se como fontes históricas, basicamente, os documentos escritos, especialmente os de origem oficial, ou seja, vinculados ao Estado. Os avanços no âmbito da história e da historiografia, seja pelo advento da Escola dos Annales, pela ampliação do número de pesquisadores vinculados ao marxismo, ou, ainda, por uma renovação dentro do próprio positivismo, possibilitaram uma ampliação no conceito, uso e interpretação das fontes históricas. As fontes oficiais tornaram-se insuficientes para a compreensão de aspectos fundamentais do processo histórico e educativo. As novas correntes historiográficas criticaram o jargão positivista de que as fontes falam por si e, em consequência disso, a ideia de neutralidade dos historiadores. O conceito de neutralidade deu lugar ao de intencionalidade. Essa mudança conceitual deu mais respaldo ao trabalho dos historiadores, na medida em que as investigações passaram a ter um duplo sentido, ou seja, "a intenção do agente histórico presente no documento e a intenção do pesquisador ao se acercar desse documento" (VIERA, 1995, p. 15). ${ }^{3}$ Daí a necessidade de enfatizar que são as perguntas que o pesquisador faz aos documentos que lhes conferem sentido e, no limite, respondem a determinados fatos.

Isso nos remete à discussão sobre os tipos de fontes que são utilizadas pelos historiadores. Trata-se do debate sobre o conceito de fontes primárias ou diretas e fontes secundárias ou indiretas. $\mathrm{O}$ emprego da nomenclatura primária e secundária vem perdendo espaço, frente ao uso da expressão direta $e$ indireta ou simplesmente fontes. Como estabelecer a diferença? Segundo Aróstegui, uma fonte classificada de direta é "um escrito ou relato de alguma testemunha presencial de um fato, de um protagonista, de uma documentação", que emana "diretamente do ato em estudo". Já a fonte indireta é

[...] uma fonte mediada ou mediatizada, uma informação baseada, por sua vez, em outras informações não testemunhais. Em suma, tratava-se de um critério classificador aplicável aos escritos em forma de crônicas, de memória, de reportagem. As fontes eram de um ou outro tipo segundo a forma como a informação era reunida, segundo a "proximidade" da fonte em relação aos fatos narrados.

Mas, atualmente, segue o mesmo autor, "a categorização direta/indireta, sem abandonar de todo essa noção referente ao grau de originalidade da informação", que pode ser de "primeira mão ou não, deve atender primordialmente à funcionalidade ou idoneidade de uma fonte em relação ao tipo de estudo que se pretende". Dessa forma, o que define a natureza da fonte ou informação é o tipo de pesquisa que se pretende, não mais a sua origem. Assim, as "fontes podem ser diretas para um determinado assunto e indiretas para outro". Com isso, ganha mais destaque na classificação das fontes a "pertinência metodológica do que à forma de reunir a informação" (2006, p. 494-95). ${ }^{4}$

Dentre as muitas fontes que podem subsidiar as pesquisas histórico-educativas, sobressai-se a legislação educacional, devido ao grande número de temas e questões que estão explícitos e implícitos nela. Entretanto, não basta apenas nos cercarmos das leis da educação para produzirmos um estudo coerente e consistente. É essencial encontrarmos uma teoria e uma metodologia adequada para sua utilização, de forma que as leis possam revelar, muito mais do que está prescrito em seus artigos e parágrafos. Indicar procedimentos de uso e interpretação da legislação educacional é o principal objetivo do presente texto. 


\title{
Da Lei à Legislação: tipos de leis
}

Conforme definido por Montesquieu, na obra clássica Do Espírito das leis:

\begin{abstract}
As leis, no seu sentido mais amplo, são relações necessárias que derivam da natureza das coisas e, nesse sentido, todos os seres têm suas leis; a divindade possui suas leis; o mundo material possui suas leis; as inteligências superiores ao homem possuem suas leis; os animais possuem suas leis, o homem possui suas leis (MONTESQUIEU, 1979, p. 25).
\end{abstract}

Já o dicionário de Luiz Maria da Silva Pinto, publicado no século XIX, definiu lei como "a ordem física que guarda todas as coisas naturais. A regra estabelecida por Deus, pela Igreja, e pelos imperantes, quanto ao moral e civil. Regra estabelecida por uma ciência ou arte" (Disponível em: http://www.brasiliana.usp.br/dicionario/3/lei). Atualmente, o dicionário Aurélio atribui à palavra lei uma série de significados. Para efeito deste texto destaco os seguintes:

1. Regra do direito ditada pela autoridade estatal e tornada obrigatória para manter, numa determinada comunidade, a ordem e o desenvolvimento. 2. Normas ou conjunto de normas elaboradas e votadas pelo poder legislativo. 3. Obrigação imposta pela consciência e pela sociedade. 4. Domínio, poder, mando. 5. Norma, preceito, princípio, regra (FERREIRA, 2004, p 1191-92).

O contido nesses fragmentos já é suficiente para afirmar que o conceito de lei foi construído historicamente, da mesma forma que a ideia de direito.

O conceituado jurista do século XIX, José Antonio Pimenta Bueno, caracterizou as leis, enquanto a sua origem, em naturais e positivas. Segundo ele, as leis "são as normas prescritas pela razão natural esclarecida, são preceitos que resultam das condições morais dos homens, condições sem as quais não haveria ordem, nem justiça entre eles". Por sua vez, as leis positivas "são as normas prescritas pelo poder social legítimo para manter a segurança dos direitos e dirigir os diferentes serviços da sociedade". Conforme Pimenta Bueno, as referidas leis compreendiam duas classes: ou visavam "reconhecer e sancionar um preceito natural, ou a erigir uma obrigação puramente social e arbitrária". Quando levada a garantir um preceito natural, o princípio da lei deve ser "essencialmente justo". É o caso da lei que "garante a vida, a propriedade, os direitos naturais do homem, e que consequentemente pune a violência, o roubo, o homicídio". Quando a lei se ocupa de estabelecer uma obrigação social, ela pode adquirir características arbitrárias, sendo sujeita a paixões políticas, preconceitos, erros e interesses pessoais dos legisladores. (SÃO VICENTE, 2002, p. 71). ${ }^{5}$

Quando se fala em lei, logo se remete à discussão do direito do Estado e do cidadão. Para mediar as relações entre Estado e cidadão e as relações dos próprios cidadãos entre si, desenvolvem-se os ramos do direito público e do direito particular ou privado. Conforme definido por Pimenta Bueno, o direito público se ocupa das "relações do cidadão para com o Estado, relações de interesse geral", que estão acima dos anseios privados. O direito público "organiza as condições do bem-ser comum; atende e protege especialmente o interesse coletivo e por amor dele despreza o interesse individual nos casos em que lhe é subordinado". O direito particular ou privado medeia as relações entre os "indivíduos na 
razão ou intuito de seus interesses particulares". Seu preceito "é guardar as liberdades e direitos individuais, a paz e a justiça, atende o bem-ser devido ao indivíduo, e não se ocupa do bem-ser geral, senão secundariamente". Para Pimenta Bueno: "estes dois direitos ou interesses, estas duas sociedades política e civil, são ambos filhos da razão esclarecida e da complexa natureza social, ambos eles têm igual e mesmo fim, a felicidade de todos e de cada um" (2002, p. 63). ${ }^{6}$

Lourenço Trigo de Loureiro, outro conceituado jurista do Império, definiu lei como "a regra estabelecida pela Autoridade Divina para todo o gênero humano, ou a regra estabelecida por cada Autoridade humana para cada corpo político, ou Nação". Ambas as regras obrigam as pessoas a fazer "certas coisas, ou lhes proíbe a prática de outras, deixando a seu livre arbítrio algumas outras, que nem lhes manda, nem lhes proíbe que façam". São, portanto, preceptivas, proibitivas ou facultativas. Cabia ao poder soberano instituir boas leis positivas e empregar a força coletiva social com o objetivo de garantir,

a segurança, e a conservação do Corpo político, a manutenção da autoridade, que o representa interna, e externamente, e o bem geral de todos os membros, de que eles se compõe, bem, que não pode existir sem a segurança individual da pessoa, da liberdade, da propriedade e das famílias.

Reportando-se à Constituição do Império, citou, ainda o $§ 2^{\circ}$ do artigo 179, o qual determinava que a lei deveria "ser igual para todos, quer proteja, quer castigue; e não pode ter efeito retroativo" (2004, p. 9-10).

O historiador E. P. Thompson, ao investigar as origens da Lei Negra na Inglaterra, definiu o princípio liberal de igualdade perante a lei como a "retórica da igualdade". Todavia, essa retórica tinha e tem objetivos claros, pois:

Se a lei é manifestamente parcial e injusta, não vai mascarar nada, legitimar nada, contribuir em nada para a hegemonia de classe alguma. A condição prévia essencial para a eficácia da lei, em sua função ideológica, é a de que mostre uma independência frente a manipulações flagrantes e pareça ser justa. [...] O direito pode ser retórico, mas não necessariamente uma retórica vazia $(1987$, p. 354).

Portanto, existe uma lógica para que a lei se guie pelo princípio da igualdade, da justiça. Daí a relevância adquirida pelo direito na sociedade moderna.

Todavia, a institucionalização da sociedade do direito ou do ordenamento jurídico não é uma tarefa muito simples, pois no processo estão envolvidos interesses contraditórios presentes nas forças políticas, sociais, nos interesses individuais e de grupos, que compõem a sociedade. Nesse contexto, emerge o Estado e seus aparatos como instituição mediadora das contradições, tornando-se um espaço de intersecção entre as classes. Marx, ao estudar o Estado idealizado por Hegel, já alertou para o fato de que ele "não pode ser tratado como realidade simples; ele deve ser tratado como atividade, como uma atividade distinta" (MARX, 2005, P. 37). Apesar de Marx considerar que o Estado constituiu-se como braço forte da classe dominante, percebeu o seu papel como agente de transformação da realidade.

Gramsci compreendeu o alerta de Marx e definiu o Estado "como 'educador' na medida em que tende precisamente a criar um novo tipo ou nível de civilização". Segundo ele, o "Estado tende a criar e manter um certo tipo de civilização e de cidadão" e, por isso, procura "fazer desaparecer certos costumes e atitudes e a difundir outros". Os instrumentos 
auxiliares do Estado são o direito, as leis, a escola e outras instituições. Para Gramsci, o Estado

[...] é um instrumento de "racionalização", de aceleração e de taylorização; atua segundo um plano, pressiona, incita, solicita e "pune", já que, criadas as condições nas quais um determinado modo de vida é "possível", a "ação ou a omissão criminosa" devem receber uma sansão punitiva, de alcance moral, e não apenas um juízo de periculosidade genérica (GRAMSCI, 2002a, p. 28). ${ }^{8}$

Ao ver, como Gramsci, o Estado como agente de educação, como produtor e difusor de civilização, é possível compreender melhor o papel desempenhado pelo direito, pela legislação educacional, pela escola e associações e instituições filantrópicas no século XIX, visto que todos esses elementos estavam diretamente ligados ou subordinados ao Estado monárquico.

No Brasil monárquico, apesar de o Imperador dispor do poder Moderador, o governo não se caracterizou como despótico, pois a constituição foi respeitada. As poucas alterações que nela aconteceram se deram mediante debates e com aprovação no legislativo. É evidente que a legislação imperial não era avançada para a época, até porque toda a legislação traz em si as características da sociedade que a produz. No caso, uma sociedade escravocrata, conservadora, tradicional, com fortes componentes moral e religioso, mas, mesmo assim, as principais conquistas liberais foram asseguradas. A constituição constituiu-se num repositório de leis, nas quais os direitos fundamentais dos cidadãos estavam garantidos. Após a outorga da constituição, inúmeras leis foram aprovadas, visando assegurar e/ou pôr em prática os direitos fundamentais ali estabelecidos. O conjunto dessas leis denomina-se legislação.

Conforme indicado por Aurélio, legislação significa: "1. Conjunto de leis acerca de uma determinada matéria. 2. Ciência das leis. 3. A totalidade das leis dum Estado, ou de determinado ramo do direito" (FERREIRA, 2004, p. 1191). Neste texto me reportarei ao conjunto das leis que diziam respeito à educação no Brasil imperial. Dentre as leis que compunham a legislação educacional cabe destacar as seguintes: a constituição, os decretos do poder Legislativo, do poder Executivo, os regulamentos, os estatutos e regimentos internos, as resoluções, portarias, avisos, pareceres e outras decisões do governo. Hoje, esses dispositivos legais ainda são usados na administração pública e nas instituições escolares, todavia, muitos deles não têm o peso legal de que gozavam no século XIX, pois, naquele contexto, o Estado Monárquico caracterizava-se como forte, centralizado e hierarquizado. ${ }^{9}$ Vejamos sinteticamente o que significava cada uma delas, tendo como referência as definições utilizadas na época. ${ }^{10}$

A constituição era e é definida como a lei fundamental da nação. O artigo 179 da constituição de 1824, com seus trinta e cinco parágrafos, assegurava a "inviolabilidade dos Direitos Civis e Políticos dos cidadãos brasileiros, que tem por base a liberdade, a segurança individual e a propriedade" (Cf. NOGUEIRA, 2001, p. 103-6). Para garantir tais direitos foram expedidos os decretos-leis do poder Legislativo e do poder Executivo. Os decretos do poder Legislativo resultaram dos debates das referidas matérias, na Câmara dos Deputados e no Senado. Após aprovados, eram encaminhados para sanção do Imperador. São exemplos de decretos do poder Legislativo: a lei de 15 de outubro de 1827, o decreto de 17 de fevereiro de 1851, que autorizou a reforma da instrução pública na Corte. Já os decretos do poder Executivo (Imperador) tinham força de lei e, na sua maioria, não necessitavam de aprovação do parlamento.

$\mathrm{Na}$ sequência da hierarquia aparecem os regulamentos. Na interpretação do jurista 
José Antonio Pimenta Bueno:

Os regulamentos não são leis, são somente atos da administração, que estabelecem, por via de disposições metódicas e dentro da órbita das atribuições do poder Executivo os meios e detalhes convenientes para que as leis tenham boa e efetiva execução (SÃO VICENTE, 2002, p. 72).

No caso da instrução pública, os regulamentos tinham força de leis, pois eles faziam parte do decreto que os instituía, como foi o caso, por exemplo, do regulamento de 17 de fevereiro de 1854, do de 18 de janeiro de 1877 e do de 19 de abril de 1879 .

Outros documentos importantes que compõem a legislação educacional no Império eram os estatutos ou ordenação das instituições de ensino, como foi o caso do Colégio Pedro II, das faculdades de Direito e Medicina. Nas instituições de instrução primária predominavam os regimentos internos, documento padrão para todas as escolas. Os regimentos eram definidos como: direção, procedimento prudencial ou moral, norma ou diretório em que se declaram as obrigações do cargo.

Outros instrumentos de menor peso legal, amplamente utilizados no Império, os quais cumpriram importante papel no processo de organização da instrução pública, principalmente no disciplinamento dos professores, foram as resoluções, portarias, avisos e decisões. Tais recursos administrativos se caracterizaram por impor determinadas ações, fazer advertências e admoestação, cobrar resultados, dar conselhos e, também, garantir direitos. Todos estes documentos foram publicados nas Coleções das Decisões do Governo do Império do Brasil.

\section{A lei como síntese de múltiplas determinações}

Marx ao fazer a crítica à filosofia do direito de Hegel afirmou:

Hegel parte do Estado e faz do homem o Estado subjetivado; a democracia parte do homem e faz do Estado o homem subjetivado. Do mesmo modo que a religião não cria o homem, mas o homem cria a religião, assim também não é a constituição que cria o povo, mas o povo que cria a constituição.

E, ao se colocar em defesa da democracia, complementou: "O homem não existe em razão da lei, mas a lei existe em razão do homem, é a existência humana, enquanto nas outras formas de Estado o homem é a existência legal" (2005, p. 50. Grifos do autor).

Essa afirmação de Marx, de que o homem não existe em função da lei, mas sim que a alei existe em função do homem, permite-me afirmar, com segurança, que as leis e a legislação foram e são construídas historicamente pelas ações humanas. A referida afirmação ganha respaldo e relevância ao acatarmos, também, as ideias defendidas por Gramsci. Segundo o conceituado pensador italiano "a 'natureza humana' é o 'conjunto das relações sociais"”. No entendimento de Gramsci, na natureza humana está presente "a ideia do devir", ou seja, "o homem 'devém', transforma-se continuamente com as transformações das relações sociais", e, por sua vez, as relações sociais expressam os "diversos grupos de homens que se pressupõem uns aos outros, cuja unidade é dialética e não formal" (2004, p. 245). Nesse constante devir do homem e da sociedade, as leis têm um papel fundamental como instrumento de mediação das relações sociais, das contradições presentes entre os grupos, constituindo-se em mecanismo de disciplinarização dos conflitos e contradições sociais. As leis são, portanto, sínteses de múltiplas determinações e estão em constante transformação. 
As leis não são frutos de poderes sobrenaturais presentes no Estado, mas sim de criações humanas, pois, como afirmou Marx, “o Estado só é ativo por meio dos indivíduos" (2005, p. 42). Na ação estatal ou política, o que se destaca nos indivíduos, não são as características físicas, mas, sim as sociais, políticas e coletivas, independentemente do regime de governo. Tanto no regime monárquico, no despótico, ditatorial ou democrático, o governo é exercido por indivíduos sociais e políticos, portanto, sujeitos portadores de sonhos, desejos, paixões e interesses, os quais estão refletidos nas medidas adotadas por esses indivíduos, na gerência e administração do Estado. O que diferencia um regime do outro é a forma de discussão, aprovação e execução das leis. Enquanto na democracia, as leis são resultado de debates travados na sociedade e no parlamento, nos governos despóticos e ditatoriais, as leis são impostas de cima para baixo. Todavia, o fato de as leis serem impostas, não miniminiza o seu caráter de síntese, visto que a imposição de ações mais duras, geralmente, justifica-se pelo aumento da resistência ou por pressão de determinados setores da sociedade.

Toda lei é uma síntese. Todavia, ao colocá-la em execução, as contradições se revelam, pois, interesses particulares ou de grupos são contestados, as resistências se acentuam, as falhas da lei aparecem. Tais contradições aceleram o debate e novas alternativas são propostas, novas leis são aprovadas. Com a legislação também acontece o processo de tese, antítese e síntese. Se o homem e a sociedade são um constante devir, como afirmou Gramsci, o mesmo acontece com as leis, pois, a legislação foi e é o mecanismo instituído pela sociedade para mediar esse constante vir a ser do homem e suas relações sociais.

Os Estados modernos foram organizados tendo por base os três poderes: o Legislativo - responsável pela aprovação das leis, o Executivo - responsável pela execução das leis e o Judiciário - responsável por fazer cumprir as leis. De maneira geral, cabe ao poder Legislativo a aprovação das leis gerais, leis norteadoras que estabelecem princípios, diretrizes, direitos e deveres. A maior ou menor força e/ou importância do poder Legislativo, depende do regime de governo presente em cada Estado. No caso do Brasil monárquico, o poder legislativo tinha seus poderes limitados, principalmente nas províncias. O sistema dos três poderes adotado pela maioria dos estados modernos reserva poder normativo, com força de lei, a vários segmentos da hierarquia administrativa ligada ao executivo e ao judiciário para regulamentar alguns dispositivos das leis gerais. Dessa forma, resoluções, regimentos, pareceres, deliberações, avisos, portarias, etc. foram e são expedidos por órgãos da administração ou conselhos, que muitas vezes exerceram/exercem mais força de lei do que a própria lei. Daí a importância de conhecer todos os mecanismos utilizados para a execução das leis, quando o objeto de análise for a legislação.

Segundo Gramsci, "o conceito de 'legislador' não pode deixar de identificar-se com o conceito de 'político'. Como todos são "políticos', todos são também 'legisladores"”. Mas, é evidente que há distinções entre os vários grupos de legisladores. Conceitualmente, o termo legislador "tem um significado jurídico-estatal preciso, isto é, significa aquelas pessoas que estão habilitadas pelas leis para legislar", no caso, o poder Legislativo. Gramsci foi além, ampliando consideravelmente o conceito de legislador, ao considerar que,

todo homem, na medida em que é ativo, isto é, vivo, contribui para modificar o ambiente social em que se desenvolve (para modificar determinadas características dele ou para conservar outras), isto é, tende a estabelecer "normas", regras de vida e de conduta. [.[..] Um pai é um legislador para os filhos, mas a autoridade paterna será mais ou menos consciente e mais ou menos obedecida, e assim por diante. Em geral, 
pode-se dizer que a distinção entre o conjunto dos homens e outros homens mais especificadamente legisladores é dada pelo fato de que este segundo grupo não só elabora diretrizes que se deve tornar norma de conduta para os outros, mas, ao mesmo tempo, elabora os instrumentos através dos quais as próprias diretrizes serão "impostas" e será controlada sua aplicação.

Para o autor, mesmo que um determinado indivíduo não seja imbuído do poder jurídico de legislar, ele executa tal função, na medida em que aceita as "diretrizes de outros; executando-as, controla sua execução também por parte dos outros, compreendendo-as em seu espírito, divulga-as, quase transformando-as em regulamentos de aplicação particular a zonas de vida restrita e individualizada" (2002a, p. 301-2). ${ }^{11}$

Tais considerações de Gramsci nos fazem perceber o quão complexo são os estudos que se ocupam da legislação como objeto de pesquisa. Não basta interpretar a lei pela lei. É preciso compreender as várias dimensões e analisar as ações dos elementos envolvidos no processo de discussão, aprovação e execução. Daí a importância de se fazer a devida contextualização, levando em conta os aspectos, políticos, econômicos, sociais, culturais, religiosos, morais etc.

Ao analisar os vários momentos da legislação educacional brasileira nos séculos XIX e XX, podemos chegar a uma conclusão óbvia, mas que tende a ser ignorada pelos estudiosos, quando não fazem as devidas considerações sobre o processo de aprovação e execução das leis. Nesse período, tivemos leis aprovadas a partir de um amplo debate na sociedade, nas instituições e no parlamento. Tivemos também leis que foram impostas por governos centralizados e ditatoriais. De modo geral, as leis aprovadas mediante amplos debates tendem a constituir-se mais como diretriz e, tendo presente um elevado grau de utopia, quanto aos resultados, à participação e envolvimento dos segmentos diretamente relacionados. Já, na legislação imposta, o que prevalece é o caráter pragmatista, ou seja, os aspectos práticos de aplicação e execução das leis visando a resultados imediatos. Essas leis, geralmente, são detalhistas e procuram normatizar as ações dos diversos sujeitos envolvidos no processo. No século XIX, é exemplo do primeiro caso a lei de 15 de outubro de 1827 e, do segundo, o decreto $\mathrm{n}^{\circ}$ 1331-A, de 17 de fevereiro de 1854, também denominado de Reforma Coutto Ferraz.

Há uma forte confluência entre os historiadores, no sentido de tratar a legislação como um elemento da superestrutura, que tem como objetivo legitimar uma determinada estrutura social e ou de classe. Segundo Gramsci "a supremacia de um grupo social se manifesta de dois modos, como 'domínio' e como 'direção intelectual e moral'” (2002b, p. 62). Thompson também admitiu que a legislação cumpre tal função na sociedade, quando assinalou que,

[...] a lei é por definição, e talvez de modo mais claro do que qualquer outro artefato cultural ou institucional, uma parcela de uma "superestrutura" que se adapta por si às necessidades de uma infraestrutura de forças produtivas e relações de produção. Como tal, é nitidamente um instrumento da classe dominante de fato: ela define e defende as pretensões destes dominantes aos recursos e à força de trabalho - ela diz o que será propriedade e o que será crime -, e opera como mediação das relações de classe com um conjunto de regras e sanções adequadas, as quais, em última instância, confirmam e consolidam o poder de classe existente (1987, p. 349-50. Grifo do autor).

Todavia, no entendimento de Thompson, a lei não pode ser reduzida apenas a uma 
espécie de máscara que legitima o domínio de uma classe, pois, "a 'lei' estava profundamente imbricada na própria base das relações de produção, que teriam sido inoperantes sem ela". Na sociedade de classes, a lei se caracteriza mais como um espaço de conflito do que de consenso, visto que as relações de classes se expressam, "não de qualquer maneira, mas através das formas da lei" (Idem, p. 352-53. (Grifos do autor). ${ }^{12} \mathrm{Se}$, "de um lado, é verdade que a lei realmente mediava relações de classe existentes, para proveito dos dominantes", do outro, "a lei mediava essas relações de classe através de formas legais, que continuamente impunham restrições às ações dos dominantes". A partir dessas evidências, não se pode chegar a "uma conclusão simples (lei = poder de classe), mas a uma conclusão complexa e contraditória" (Idem, p. 356). ${ }^{13}$

Thompson esclarece melhor o que entende por complexo e contraditório no exercício e domínio da lei. É verdade, diz ele, "que, na história, pode-se ver a lei a mediar e legitimar as relações de classe existentes". Todavia, "essa mediação, através das formas da lei, é totalmente diferente do exercício da força sem mediação". No seu entendimento, "as formas e a retórica da lei adquirem uma identidade distinta que, às vezes, inibem o poder e oferecem alguma proteção aos destituídos de poder". Por isso, ao se considerar a lei, "enquanto regras e procedimentos formais e como ideologia, não pode ser proveitosamente analisada nos termos metafóricos de uma superestrutura distinta de uma infra-estrutura" (Idem, p. 358).

Ao se conceber e analisar a legislação como ideologia, tanto Thompson, como Gramsci nos alertam para que tomemos os procedimentos adequados, ou seja, situar historicamente os conflitos. Segundo Gramsci: "Não se deve conceber a 'ideologia', a doutrina como algo artificial e sobreposto mecanicamente (como uma roupa sobre a pele), mas historicamente, como uma luta incessante" (2002a, p. 199), entre as classes sociais, entre os interesses individuais e coletivos ou entre o Estado e a sociedade civil. Thompson vê a lei como reguladora dos conflitos humanos e sociais, por isso, traz em si o princípio da igualdade, pois,

[...] "a lei”, enquanto uma lógica da igualdade, sempre deve tentar transcender as desigualdades do poder de classe, ao qual é instrumentalmente atrelada para servi-lo. E "a lei" enquanto ideologia, a qual pretende reconciliar os interesses de todos os graus de homens, sempre deve entrar em conflito com o sectarismo ideológico de classe (1987, p. 360-61).

De fato, a lei cumpre uma função ideológica na sociedade, mas isso não significa que tal função seja usada exclusivamente em beneficio da classe social privilegiada. Em muitos momentos da história, a lei serviu (e deve continuar servindo) como elemento de luta contra os privilégios. A lei constitui-se, portanto, num componente central na luta pela hegemonia, principalmente numa sociedade democrática. ${ }^{14}$

Seja a lei vista como superestrutura, que legitima os interesses de determinadas classes sociais, seja como ideologia ou como mediadora dos conflitos, como espaço de contradição ou consenso, ou como garantia de direitos, ela não deixa de ser uma síntese de múltiplas determinações em constante processo de mudança. A lei é, portanto, dialética.

\section{Da utilização da legislação como fonte: sugestões metodológicas}

Entendo que as leis relacionadas à educação constituem-se como fontes históricas documentais da mais alta importância para se produzirem conhecimentos históricoeducativos. Todavia, não basta analisar a legislação de forma mecânica, ou seja, a lei pela lei, sem (ou só) estabelecer ligações entre o poder político hegemônico, sem fazer 
conexões entre a legislação educacional e o projeto político social ou a própria prática social, sem considerar as reações (incorporações/resistências) da sociedade ou setores diretamente afetados pelas medidas legais etc. Além de razoável experiência no trato com fontes primárias, encontrei suporte em vários autores, especialmente Dário Ragazzini, para pensar uma metodologia mais abrangente e segura para lidar com a legislação educacional.

No entendimento de Dário Ragazzini, as fontes podem ser representadas por um "complexo estratificado composto de vários níveis de relações" que se entrecruzam, produzindo "uma superposição de estratificações históricas". Ele sintetiza essas relações em três níveis, a saber: o primeiro é a relação nas quais nasce e se produz o documento ou seja, o contexto; o segundo é a relação que, no âmbito dos acontecimentos, seleciona, conserva, inventaria e cataloga o documento, as quais podem ser "causais, intencionais ou preterintencionais"; o terceiro é a relação do leitor intérprete, ou seja, as questões ou interrogações que ele faz aos documentos, a partir das suas concepções e interesses de pesquisa. (2001, p. 14-5). Um estudo coerente e consistente deve levar em consideração esses três níveis de relação ao utilizar-se de qualquer tipo de documentação. Daí a necessidade de se fazer uma crítica aos documentos, refletir sobre os motivos e, no caso da legislação, o processo de elaboração ou implantação; identificar quem foram seus autores, por que foi conservado/preservado, ou seja, deve-se lê-lo dentro de seu contexto e a partir de diversas variáveis.

A proposta de Ragazzini, na verdade, apresenta-se como o exercício da dialética no processo de pesquisa, de maneira que haja uma graduação entre o contexto, a utilização das fontes e as interpretações do pesquisador. No meu entendimento, tal exercício é mais complicado do que realizar uma leitura dialética das contradições sociais. A partir dessa constatação passo a refletir sobre os três níveis de relações sugeridos por Ragazzini. Os exemplos utilizados têm como referência a educação no período imperial, objeto de minhas pesquisas.

Compreender o contexto de produção da legislação é algo indispensável para captar os objetivos das leis. Não se trata apenas do contexto macro, ou seja, os fatores econômicos, políticos, sociais e culturais, pois nem sempre os objetos de análise são as leis gerais, tanto federais, como estaduais e municipais, produzidas pelo poder Legislativo. São leis da educação, também as produzidas por ministérios, secretarias de educação, ou setores intermediários da hierarquia administrativa, por órgãos colegiados (conselhos), leis internas às instituições de ensino etc. Ter clareza do contexto geral é muito importante, mas só ele não basta, pois, conforme a legislação em análise, é necessário se ocupar do contexto micro, ou seja, compreender os meandros da hierarquia administrativa, dos colegiados e instituições de ensino. No caso de leis aprovados no parlamento, é importante conhecer o percurso de tramitação da lei, o conteúdo dos debates, identificar os pontos de conflitos, os interesses em disputa. Como nos alerta Gramsci: é preciso levar "em conta que muitos atos políticos são motivados por necessidades internas de caráter organizativo, isto é, ligados à necessidade de dar coerência a um partido, a um grupo, a uma sociedade" (2004, p. 239). ${ }^{15}$ Em muitos casos, também é essencial compreender o papel desempenhado por determinados indivíduos na produção e execução de medidas educativas.

Outro aspecto importante para se compreenderem as dimensões do alcance da lei é não vê-la de forma isolada, como algo estático. Quanto maior for a amplitude da lei, mais ela necessita de medidas auxiliares para a sua efetiva execução (leis complementares, diretrizes, resoluções, pareceres, instruções, portarias, avisos etc.), pois é somente no efetivo exercício da lei que as contradições se revelam, as resistências aparecem, e os mecanismos de burla passam a ser utilizados por parte dos envolvidos com mais 
frequência. Por isso, entendo que os estudos sobre a legislação devem levar em conta as medidas complementares, sejam na forma de novas leis ou como instruções e avisos, pois muitas vezes elas modificam alguns dos dispositivos da lei geral, contribuindo para aumentar o sucesso ou fracasso das medidas legais. Um exemplo claro disso aconteceu com a lei de 15 de outubro de 1827. Depois de amplamente debatida por deputados e senadores, a lei foi aprovada e sancionada pelo Imperador. Ao entrar em execução, as dificuldades apareceram, levando o Imperador, através do Ministério do Império, e os parlamentares a adotarem uma série de medidas para viabilizar sua execução. Tais medidas acabaram modificando consideravelmente os dispositivos da lei e consequentemente os objetivos propostos inicialmente.

No caso do Brasil, tanto imperial, como republicano, há outras situações que devem ser consideradas quando se estuda a legislação educacional. Uma delas é o elevado nível de burocratização do Estado. No período imperial predominou a centralização política e administrativa, mesmo depois do Ato Adicional de 1834. Antes do Ato, todas as ações relacionadas à criação de escolas e nomeação de professores deveriam ser aprovadas pela Assembleia Geral e sancionadas pelo Imperador. Depois do Ato Adicional, o poder de criar escolas e definir os salários dos mestres passou a ser atribuição das assembleias provinciais. Com isso, o processo de criação de escolas ficou mais rápido. Todavia, as assembleias provinciais gozavam de pouco poder, pois ele continuava concentrado no cargo de presidente da província, braço do Imperador. A nomeação dos presidentes das províncias era atribuição exclusiva do Soberano, assim o presidente constituía-se mais como um representante da Coroa na província, do que um governante legitimamente provincial. Como indicou Marx, "a manutenção do interesse universal do Estado e da legalidade, encontram-se nos delegados do poder governamental, nos funcionários estatais executivos e nas autoridades colegialmente constituídas que convergem no monarca" $\left(2005\right.$, p. 64). ${ }^{16}$

Além da centralização e burocratização do poder no topo da hierarquia administrativa, havia também as funções intermediárias correspondentes aos cargos de inspetores gerais, inspetores de distrito ou delegados, dos inspetores paroquiais (além dos fiscais das câmaras e dos padres, que também exerciam influência sobre o trabalho dos professores), chegando até aos professores e destes aos alunos. Os cargos intermediários não tinham apenas a função de cumprir as leis, mas também poderiam criar normas e regras e impô-las aos seus subordinados. Os inspetores gerais, tanto na Corte, como nas províncias foram exímios legisladores. Detentores de um elevado poder, atribuído-lhes pela legislação (regulamentos), participaram diretamente da elaboração ou reorganização dos regulamentos gerais da instrução pública, organizaram os regimentos internos às escolas, instruções normativas para a inspeção, avisos, portarias etc., tudo com força de lei, as quais deveriam ser seguidas pelos seus subordinados. Conforme observou Marx:

\footnotetext{
A burocracia é um círculo do qual ninguém pode escapar. Sua hierarquia é uma hierarquia do saber. A cúpula confia aos círculos inferiores o conhecimento do particular, os círculos inferiores confiam à cúpula o conhecimento do universal e, assim, eles se enganam reciprocamente (Idem, p. 66. Grifo do autor). ${ }^{17}$
}

Quem mais sofria com a burocratização da estrutura era o professor, que necessitava se submeter periodicamente às vontades dos delegados ou inspetores paroquiais para conseguir os atestados de frequência e, assim conseguir receber seu salário.

Outra questão importante a ser considerada ao contextualizar determinado período da educação brasileira, a qual tem impacto direto no efetivo exercício da legislação é o 
problema da descontinuidade nas políticas educacionais. A descontinuidade política e administrativa leva muitas ações do Estado a um constante recomeço e a uma constante crítica à legislação, sem a preocupação de garantir o efetivo exercício das leis existentes. Com a justificativa de instituir um novo projeto alteram-se as leis ou alguns dos seus dispositivos, instaurando-se um novo ciclo de utopia. Grande parte de nossos políticos e gestores não perceberam (e ainda não percebem) que os resultados das ações implantadas no campo da educação só podem ser visto a longo prazo. Quando os resultados começam a aparecer, acaba o mandato, nova equipe assume, e o ciclo recomeça. Se hoje ainda temos sérios problemas com a descontinuidade nas políticas educacionais, podemos imaginar como era a situação no período imperial.

Pela lógica, um governo monárquico deveria ser estável, porém essa não foi a situação vivida no período do Imperial, quando nos reportamos aos auxiliares diretos do Imperador, como os ministros e presidentes de províncias. A rotatividade entre os ocupantes desses cargos é algo impressionante. Vejamos alguns exemplos: entre 1822 e 1889 existiram 105 mandatos diferentes à frente do cargo de Ministro do Império, pasta responsável pela instrução pública. Na Província do Rio de Janeiro, foram 86 mandatos diferentes, entre presidentes e vice-presidentes, no período de 1834 a 1889. Em Mato Grosso, foram 68 entre 1825 e 1889. No Paraná 55, em menos de 36 anos (1853-1889). Naquelas condições, não havia muitas chances da instrução pública avançar. A história mostrou que os avanços mais significativos aconteceram nos períodos em que houve mandatos mais longos, ou seja, com o mínimo de estabilidade. ${ }^{18}$

Quando se tem por objeto a legislação, o pesquisador não pode deixar de considerar os elementos de resistência e os mecanismos utilizados para burlar a ordem estabelecida em cada contexto histórico. Ao se ocupar do estudo das leis, Gramsci afirmou:

De fato, uma lei encontra quem a infringe: 1) entre os elementos sociais reacionários que a lei alijou do poder; 2) entre os elementos progressistas que a lei reprime; 3 ) entre os elementos que não alcançaram o nível de civilização que a lei pode representar.

Segundo ele, "a função de polícia de um partido" ou Estado "pode ser progressista ou reacionária". É progressista quando procura "manter na órbita da legalidade as forças reacionárias alijadas do poder e a elevar ao nível da nova legalidade as massas atrasadas". A ação é "reacionária quando aspira a reprimir as forças vivas da história e a manter uma legalidade ultrapassada, anti-histórica, tornada extrínseca" (2002a, p. 308). As três situações indicadas por Gramsci sintetizam os elementos de resistência das leis. A predominância de uma delas depende do contexto político e do grau de desenvolvimento das forças produtivas. Em se tratando das leis educacionais, os três elementos se mostram presentes, mas, geralmente predomina o terceiro.

No período imperial, a resistência predominou no terceiro grupo, ou seja, entre os elementos que não compreendiam ou não viam o nível de civilização que a lei poderia representar. A resistência ao processo de escolarização era muito forte entre os pobres livres. Sobre esse aspecto, cabem as seguintes perguntas: numa sociedade hierarquizada e conservadora, ancorada na escravidão, com uma economia e vida rural predominante, em que o trabalho era basicamente manual, qual o sentido da escola? Que vantagens os pais teriam em obrigar seus filhos a frequentar uma escola excessivamente violenta e punitiva? As pessoas simples não conseguiam ver nos conhecimentos escolares um futuro melhor para seus filhos. Daí a resistência dos pais em mandar os filhos às escolas, preferindo utilizá-los como força de trabalho. Muitas tentativas foram feitas para impor a obrigatoriedade escolar, pouquíssimas com sucesso. 
Ao se debruçar sobre a cultura popular inglesa, Thompson aponta elementos que ajudam a compreender a resistência à escolarização no Brasil do século XIX. A escola representava a cultura da elite e se contrapunha à "cultura costumeira", que não estava sujeita, "em seu funcionamento cotidiano, ao domínio ideológico dos governantes". A hegemonia da classe abastada era "laica, e não religiosa ou mágica", pois, no Brasil da época, havia a separação entre a igreja da "boa sociedade", a dos pobres livres e a dos escravos. Os instrumentos e imagens utilizados para controlar a cultura popular não eram os "da Igreja ${ }^{19}$ ou do carisma monárquico, mas aqueles proporcionados pela lei". A lei estabelecia os "limites tolerados pelos governantes", mas não conseguia penetrar com força nos lares das pessoas simples, de vida predominantemente rural. "Na interface da lei com a prática agrária, encontramos o costume. O próprio costume é a interface, pois podemos considerá-lo como práxis e igualmente como lei. A sua fonte é a práxis", concluiu Thompson. (1998, p. 19 e 86, respectivamente. Grifo do autor). ${ }^{20}$ Vencer a resistência, os hábitos não foi uma tarefa fácil. Muitas escolas criadas nas vilas e freguesias foram fechadas ou funcionavam com baixa frequência. $\mathrm{O}$ aumento da população escolar caminhou junto com o processo de urbanização.

O segundo nível da relação indicado por Ragazzini é o momento da seleção, conservação e catalogação dos documentos. De maneira geral, as leis oriundas do Poder Legislativo, dos órgãos superiores da administração e dos conselhos federal e estaduais de educação têm sua preservação assegurada, pois se trata de fontes oficiais que têm um caráter propositivo, deliberativo ou normativo sobre os mais variados aspectos da administração pública e educacional. Todavia, a legislação produzida na hierarquia intermediária e interna às instituições de ensino não goza da mesma sorte. Os documentos produzidos pela hierarquia administrativa intermediária, geralmente, não são preservados nos arquivos públicos, ficando sob a guarda do próprio setor. Porém, periodicamente, acontece a troca de equipes, devido à eleição de um novo governante. Geralmente, as equipes que saem levam consigo ou destroem a documentação, deixando os armários vazios, ou a equipe que chega faz um descarte geral na papelada e, assim as fontes desaparecem. O mesmo acontece na maioria das instituições de ensino. Não há uma preocupação com a preservação/conservação dos documentos produzidos, não há uma política de arquivamento.

Além da seleção dos documentos feita pelas instituições responsáveis por sua guarda, pela seleção feita pelo tempo, em muitos casos, em virtude da falta de armazenamento adequando, há também a seleção das fontes feitas pelos próprios pesquisadores. Ao escolher este ou aquele conjunto da legislação, ao privilegiar determinado tipo de leis, o pesquisador está selecionando, catalogando suas fontes. A seleção pode se dar pela escolha do método a ser empregado, pelo recorte, pelo objeto, pela forma de análise a ser desenvolvida. Isso tudo tem impacto direto nos resultados da pesquisa.

O terceiro nível é o do leitor intérprete. Como indica Ragazzini, a interpretação das fontes "está inscrita em uma operação teórica produzida no presente, relacionada a projetos interpretativos que visam a confirmar, contestar ou aprofundar o conhecimento histórico acumulado" (2001, p. 14). São, portanto, as questões do presente que dão vida ao passado. Daí a importância de se compreender e considerar os níveis anteriores para poder fazer as interrogações mais adequadas possíveis às fontes, evitando, assim, estudos anacrônicos, descontextualizados ou superficiais.

Como já enfatizado anteriormente, os documentos e as leis são expressão do passado e, como tais, estão carregados de sentidos, que evidenciam/revelam características da sociedade que os produziu. Certamente, não foram produzidos pensando nos estudos 
dos historiadores, mas, sim, visavam a atender às exigências burocráticas ou às necessidades específicas de um determinado momento histórico. Cabe, portanto, ao historiador uma tarefa muito importante no processo de produção do conhecimento. Ele "precisa ser capaz de desvelar todas as passagens que o conduzem da fonte aos diversos graus do contexto, de utilizar as fontes e os estudos correspondentes àquelas fontes de forma graduada" (Idem, p. 23).

Chamei a atenção, no tópico anterior, para o caráter de síntese que representa a legislação, principalmente a educacional. Nas leis da educação estão presentes projetos políticos e de civilização que, por si só, já colocam em contradição a cultura erudita e a popular, a modernidade e a tradição. Nas mesmas leis, também estão presentes, de forma explícita ou implícita, os valores morais, religiosos, cívicos e sociais. Estão presentes identidades étnico-culturais, sociais e profissionais. Aparecem também preconceitos, discriminações e exclusões. As leis instituem direitos e deveres dos cidadãos, mecanismos de controle e inspeção, criam estruturas de poder, estimulam a concorrência entre indivíduos e instituições, fortalecem o Estado ou a iniciativa privada, implantam sistemas de financiamento etc. Como interpretá-las? Como diferenciar o que é circunstancial do que é permanente?

Pelo que já foi argumentado até agora, fica claro que os estudos envolvendo a legislação não podem ficar restritos a elas. É necessário se cercar de outras fontes para se chegar a uma compreensão mais ampla do processo. Conforme indicado por Ragazzini, a história de determinado período, de determinados processos educativos ou de determinada

[...] escola se escreve, também a partir da análise dos dados parlamentares, da legislação, das normas e da jurisprudência, da administração pública, dos balanços econômicos, enfim, de um conjunto de fontes que provém muito mais da história legislativa, do direito, da administração pública, da economia, do Estado, dos partidos políticos, que da história da escola e da educação (Idem, p. 19).

Articular a legislação com as fontes mais gerais da educação e as fontes específicas de um determinado processo educativo ou do interior das instituições com as questões mais gerais da sociedade é um fator necessário para se chegar a um conhecimento mais acertado sobre o passado. Ou seja, quanto mais conhecermos do contexto, quanto mais clareza tivermos do que queremos investigar, mais adequadas serão nossas interrogações e questionamentos às fontes e, consequentemente, melhores serão nossas interpretações.

Lourenço Trigo Loureiro, ao fazer uma compilação das leis que se constituíam como fonte do direito civil brasileiro, em meados do século XIX, já nos orientava sobre as formas de analisar, interpretar e estudar a legislação. Segundo ele, "interpretar é investigar o verdadeiro sentido de uma lei" (2004, p. 28). Como seu objeto estava centrado no direito, dividiu a interpretação em gramatical e lógica, todavia suas reflexões também dão fundamentação para o uso e interpretação das leis como fonte histórica. A "interpretação gramatical, ou literal" se ocupa do "sentido das palavras da lei segundo a propriedade das mesmas palavras e uso de falar". Assim, ao intérprete cabe "conhecer não só as várias significações, que as palavras da lei tinham ao tempo, em que ela foi feita, e a história da língua; mas também a origem, o progresso, e a história da jurisprudência portuguesa, e brasileira". Por sua vez, "a interpretação lógica deduz da lei escrita, por meio do raciocínio, o que não está escrito nela, mas se contém no seu espírito, e na razão, que a ditou". Portanto, ocupa-se em "descobrir a razão e o espírito da lei pelo emprego de certos princípios, como são: $1^{\circ}$ a analogia; $2^{\circ}$ o gênio do século e do legislador; $3^{\circ}$ os costumes antigos; $4^{\circ}$ as causas que deram ocasião à lei; $5^{\circ}$ o direito natural, a história" (Idem, p. 29- 
$30)^{21}$

Trigo de Loureiro foi além e acrescentou: "as leis devem ser interpretadas no sentido compatível com a equidade natural", a qual "deve ser regulada segundo a natureza, gravidade, e importância do negócio, ou coisa, de que se tratar, segundo as circunstâncias das pessoas, e dos lugares, segundo o estado da civilização do país, e segundo o gênio e índole dos seus habitantes" (Idem, p. 34). Ao apontar os diversos aspectos envolvidos no ato de interpretar as leis, o autor nos ensina que é necessário buscar o pleno conhecimento do contexto de discussão, aprovação e execução das leis. É preciso considerar a linguagem, a tradição, o desenvolvimento econômico e social, as forças políticas, etc. Ao adotarmos tais procedimentos evitaremos análises anacrônicas e diminuiremos os riscos de fazermos julgamentos tendenciosos ou preconceituosos sobre os atos humanos do passado.

Augusto Teixeira de Freitas, outro jurista do século XIX, também nos ofereceu alguns elementos fundamentais para analisar e interpretar a legislação. Segundo ele, é necessário

Examinar as leis em seus próprios textos sem influência de alheias opiniões, comparar atentamente as leis novas com as antigas, medir com precisão o alcance e as consequiências de umas e outras; eis o laborioso processo, que empregado temos para conhecer a sustância viva da legislação (2003, p. XXXVI). ${ }^{22}$

Concordo plenamente com os procedimentos sugeridos pelo autor. Sempre devemos fazer o máximo de esforço para ter acesso à fonte original e, assim, fugir do recurso do apud e de intérpretes. É indispensável ler atentamente toda a legislação pertinente ao recorte estabelecido, de preferência em ordem cronológica e seguindo a hierarquia das leis, ou seja, da mais geral para a mais específica. A leitura em ordem cronológica e hierárquica das leis facilita a comparação, evidencia melhor as articulações e lacunas, leva à percepção de rupturas e continuidades, permite construir uma biografia dos conceitos, ideias e inovações sugeridas. Para medir com precisão o alcance ou falhas das leis, o pesquisador deve analisar as medidas complementares ou auxiliares expedidas pelos órgãos ou instituições responsáveis pela execução da lei, valer-se de estatísticas e avaliações e do desenvolvimento social ou cultural do período. Como indica Teixeira de Freitas, o trabalho é laborioso, mas quando o pesquisador conseguir articular contexto, fontes e interpretações, os resultados certamente serão substanciosos, coesos e consistentes.

\section{Conclusões}

Pelo exposto até aqui podemos estabelecer as seguintes conclusões:

As fontes ou documentos são requisitos fundamentais para a produção e sistematização do conhecimento histórico. Em contrapartida, a relação do historiador com as fontes deve constituir-se numa das bases fundamentais da pesquisa histórica.

Conforme sugerido por Dario Ragazzini, o trabalho do historiador pode ser representado "como uma ponte entre o presente e o passado - que adquire a sua estabilidade à medida que estabelece um balanceamento adequado entre a localização, a leitura e o emprego das fontes", com os problemas historiográficos enfrentados no presente, o uso dos esquemas interpretativos visando à construção/reconstrução do conhecimento histórico. (2001, p. 15).

Se fôssemos fazer uma análise das pesquisas no campo da história encontraríamos uma parte significativa das obras, nas quais, os autores privilegiaram o estudo do contexto macro, em relação ao objeto, tendo como referência determinadas teorias ou autores, sem 
se preocupar se as fontes utilizadas explicam o contexto e justificam as interpretações. Outra parte das obras, também significativa, nas quais houve o privilegiamento das fontes, ou seja, os autores deram voz excessiva às fontes, sem contextualizá-las e interrogá-las adequadamente. Há ainda um terceiro grupo de obras, cuja ênfase está nos intérpretes. Nesse grupo, há aqueles que tratam a história como uma narrativa, na qual tudo é verdade; há os que, com base numa teoria, explicam determinado fato ou contexto, de forma anacrônica ou condenando aqueles homens e mulheres por não terem solucionado os problemas que enfrentavam. Há também, é claro, um quarto grupo de pesquisadores, que felizmente cresce, os quais procuram mediar o contexto, o uso das fontes e as interpretações. Não há dúvidas de que, para que o conhecimento produzido seja o mais acertado possível sobre o passado, é fundamental que haja um equilíbrio entre o contexto, as fontes e as interpretações; é essencial estabelecer inter-relações, pois, caso contrário, o conhecimento histórico produzido será mutilado.

Mesmo tomando estes cuidados, devemos ter clareza de que a tarefa de recontar ou reconstruir a história é sempre limitada. Temos de aceitar que não é possível compreender o passado em plenitude. Por isso, é importante enfatizar que são as perguntas que o pesquisador faz aos documentos que lhes conferem sentido e, no limite, respondem a determinados fatos. "Nesse sentido é que se diz que uma fonte nunca está esgotada e que a história é sempre reescrita, na medida em que depende do problema proposto a ser enfrentado e, portanto, do tipo de pergunta que lhe é formulada" (LOPES e GALVÃO, 2001, p. 92).

Se as fontes são o ponto de origem, a base ou sustentáculo para a produção do conhecimento histórico, cabe a nós, enquanto indivíduos, grupos ou instituições criar, organizar e manter formas e instrumentos para preservar e disponibilizar as fontes aos futuros pesquisadores em história da educação. Da mesma forma, é de grande importância nos empenharmos para desenvolver uma consciência e uma prática documentária de catalogação e conservação dos documentos nas diversas instituições escolares e nas esferas administrativas do Estado. Ao mesmo tempo em que buscamos uma nova consciência documentária, também devemos nos preocupar com a difusão das fontes e dos conhecimentos produzidos, criando instrumentos adequados para facilitar a circulação das informações, tais como: catálogos, livros, coletâneas, site na internet, DVDs etc. Feito isso, estaremos preservando nossa memória e fortalecendo nossa identidade.

A legislação educacional foi aqui definida como síntese de múltiplas determinações, porque ela foi consequência de e/ou, nela estão presentes utopias, sonhos, desejos, projetos políticos, interesses pessoais e de grupos, direitos e deveres dos cidadãos ou categorias profissionais, planos de carreiras, preconceitos, inclusões/exclusões, enfim, todas as contradições da sociedade.

Ficou claro que as leis não são apenas instrumento de manipulação, que legitimam o poder das elites. Elas são também garantias de direitos e se constituem como instrumento de mediação e consenso das contradições sociais. Thompson, ao buscar compreender o papel da legislação na sociedade percebeu que existe uma significativa "diferença entre poder arbitrário e o domínio da lei’. Diante de tal constatação concluiu:

Devemos expor as imposturas e injustiças que podem se ocultar sob essa lei. Mas o domínio da lei em si, a imposição de restrições efetivas ao poder e a defesa do cidadão frente às pretensões de total intromissão do poder parecem-me um bem humano incondicional. Negar ou minimizar esse bem, neste século perigoso em que continuam a se ampliar os recursos e as pretensões do poder, é um erro temerário de abstração intelectual. Mais que isso, é um erro que se reproduz e aumenta por si 
mesmo, estimulando-nos a desistir da luta contra as más leis e procedimentos classistas e a nos desarmar perante o poder. Significa lançar fora toda uma herança de luta pela lei, e dentro das formas da lei, cuja continuidade jamais poderia se interromper sem lançar homens e mulheres num perigo imediato (1987, p. 357-58. Grifo do autor).

Enquanto cidadãos comprometidos com o desenvolvimento e a justiça social, precisamos participar ativamente da luta contra o poder arbitrário, tendo por base as leis existentes e, ao mesmo tempo, nos envolver ou promover debates políticos e sociais, visando a elaborar novas leis mais eficientes do que as que já existem. Enquanto historiadores, temos a possibilidade de compreender historicamente os limites das leis, perceber avanços e retrocessos, rupturas e continuidades e, dessa forma, contribuir efetivamente para a feitura de leis coerentes com os níveis de desenvolvimento e necessidades sociais. Está clara, portanto, a importância da legislação, enquanto fonte histórica e enquanto instrumento de luta pela construção de igualdades sociais.

\section{Bibliografia}

ARÓSTEGUI, J. A pesquisa histórica: teoria e método. Bauru: Edusc, 2006.

BASTOS, A. C. Tavares. A província: estudo sobre a descentralização no Brasil. 3. ed. São Paulo: Nacional, 1975.

BENTHAM, Jeremy. Uma introdução aos princípios da moral e da legislação. Trad. de Luiz João Baraúna. 2. ed. São Paulo: Abril cultural, 1979.

Biblioteca Brasiliana da USP. Disponível em: http://www.brasiliana.usp.br/dicionario

CASTANHA, André Paulo. $O$ Ato Adicional e a instrução elementar no Império: descentralização ou centralização? São Carlos-SP: UFSCar, 2007.

Dicionário da língua portuguesa, por Luiz Maria da Silva Pinto, natural da Província de Goiás, na Tipografia de Silva, 1832. Disponível em: http://www.brasiliana.usp.br/dicionario

FARIA FILHO, Luciano Mendes de. "A legislação escolar como fonte para a história da educação: uma tentativa de interpretação". In: civilização. Belo Horizonte: Autêntica, 1998, p. 89-125.

FARIA, Ernesto. Dicionário escolar latino português. 6. ed. $5^{\mathrm{a}}$ tir. Rio de Janeiro FAE, 1992.

FERREIRA, Aurélio Buarque de Holanda. Novo dicionário Aurélio da língua portuguesa. 3. ed. Curitiba: Positivo, 2004.

FREITAS, Augusto Teixeira de. Consolidação das leis civis. Ed fac-sim. Brasília: Senado Federal, 2003.

GRAMSCI, Antonio. Cadernos do Cárcere, vol. 1. 3. ed. Rio de Janeiro: Civilização Brasileira, 2004.

GRAMSCI, Antonio. Cadernos do Cárcere, vol. 3. 2. ed. Rio de Janeiro: Civilização Brasileira, 2002a.

GRAMSCI, Antonio. Cadernos do Cárcere, vol. 4. Rio de Janeiro: Civilização Brasileira, 2001 . 
GRAMSCI, Antonio. Cadernos do Cárcere, vol. 5. Rio de Janeiro. Civilização Brasileira, $2002 b$.

LOMBARDI, J. C. "História e historiografia da educação: atentando para as fontes". In: LOMBARDI, J. C. e NASCIMENTO, M. I. M. (Org). Fontes, História e Historiografia da Educação. Campinas: Autores Associados, 2004.

LOPES, Eliane M. T. e GALVÃO, Ana M. de O. História da educação. Rio de Janeiro: DP\&A, 2001.

LOUREIRO, Lourenço Trigo de. Instituições de direito civil brasileiro. Edição fac-sim. Brasília: Senado Federal; Superior Tribunal de Justiça, 2004.

MARX, Karl. Crítica da filosofia do direito de Hegel. Trad. de Rubens Enderle e Leonardo de Deus. São Paulo: Boitempo, 2005.

MARX, Karl. O capital: crítica da economia política. Vol. 2, 2. ed. São Paulo: Nova Cultural, 1985.

MONTESQUIEU. Do espírito das leis. Trad. de Fernando Henrique Cardoso e Leôncio Martins Rodrigues. 2. ed. São Paulo: Abril cultural, 1979.

NOGUEIRA, Octaciano. Constituições brasileiras: 1824. Brasília: Senado Federal e MCT, 2001.

ORSO, Paulino José et al. (Orgs). História da educação: levantamento de fontes e instituições escolares. Cascavel-PR: Coluna do Saber, 2008, p. 15-27.

RAGAZZINI, Dário. "Para quem e o que testemunham as fontes da história da educação?". In: Educar em revista, nº 18. Curitiba: Editora UFPR, 2001.

SÃO VICENTE, José Antonio Pimenta Bueno, Marquês de. José Antonio Pimenta Bueno, Marques de São Vicente. Org. e introd. de Eduardo Kulgelmas. São Paulo: Editora 34, 2002.

SAVIANI, Dermeval. "Breves considerações sobre fontes para a história da educação". In: LOMBARDI, J. C. e NASCIMENTO, M. I. M. (Org). Fontes, História e Historiografia da Educação. Campinas: Autores Associados, 2004.

SAVIANI, Dermeval. Política e educação no Brasil: o papel do Congresso Nacional na legislação do ensino. 3. ed. rev. Campinas: Autores Associados, 1996.

SILVA, Kalina Vanderlei. Dicionário de conceitos históricos. São Paulo: Contexto, 2005.

THOMPSON, E. P. Senhores e caçadores: a origem da lei negra. Trad. de Denise Bottmann. Rio de Janeiro: Paz e Terra, 1987.

THOMPSON, E. P. Costumes em comum. Trad. de Rosaura Eichemberg. São Paulo: Companhia das Letras, 1998.

URUGUAI, Visconde do. Visconde do Uruguai. Org. e introd. de José Murilo de Carvalho. São Paulo: Editora 34, 2002.

VIERA, Maria Pilar de Araújo et al. A pesquisa em história. 3. ed. São Paulo: Ática, 1995. 
Notas:

${ }^{1} \mathrm{O}$ presente texto é uma adaptação do $1^{\circ}$ capítulo do relatório de estágio de pós-doutorado que se encontra em fase de conclusão, junto ao Departamento de Filosofia e História da Educação da Unicamp. Três situações contribuíram diretamente para o desenvolvimento e aprofundamento deste estudo: $1^{\circ}$ - as pesquisas que desenvolvi e venho desenvolvendo sobre a história da educação imperial; $2^{\circ}$ - a leitura da bibliografia selecionada (especialmente Dario Ragazzini) e as discussões feitas junto aos alunos do Curso de Especialização em História da Educação Brasileira, ofertado pelo Grupo de Pesquisa HISTEDOPR em parceria com o Colegiado de Pedagogia da Unioeste - Campus de Cascavel nos anos de 2004, 2006 e 2008. Daquelas leituras e discussões resultou o texto: "As fontes e a problemática da pesquisa em história da educação", publicado nos anais da VII Jornada do HISTEDBR em 2007 e como capítulo de livro em 2008, In: ORSO, Paulino José et al. (Orgs). História da educação: levantamento de fontes e instituições escolares. Cascavel-PR: Coluna do Saber, 2008, p. 15-27; $3^{\circ}$ - a leitura do texto de: FARIA FILHO, Luciano Mendes de. "A legislação escolar como fonte para a história da educação: uma tentativa de interpretação". In: (Org). Educação, modernidade e civilização. Belo Horizonte: Autêntica, 1998. p. 89-125. O autor indicou de forma sintética algumas dimensões da lei que podem ser exploradas nas investigações: a lei como ordenamento jurídico, como linguagem, como prática social, como prática ordenadora das relações sociais, a lei como campo de expressão e construção das relações e lutas sociais.

${ }^{2}$ Professor do Colegiado de Pedagogia da Unioeste - Campus de Francisco Beltrão. Membro do Grupo de Pesquisa: História, Sociedade e Educação no Brasil - HISTEDOPR - GT da Unioeste. Historiador, mestre e doutor em Educação. Atualmente desenvolve estágio de Pós-doutorado na área de Filosofia e História da Educação na Faculdade de Educação da Unicamp, sob a supervisão do Professor Dermeval Saviani. Premiado com Bolsa especial da CAPES, em virtude de ter vencido o Prêmio Capes de Teses 2008, na área de Educação. E-mail: andrecastanha@brturbo.com.br

${ }^{3}$ Sobre o papel objetivo e subjetivo dos historiadores, Dario Ragazzini pondera: "Se do primeiro risco estamos, hoje, mais advertidos, quanto ao segundo, permanecem presentes os riscos de estabelecermos correlações enganosas entre as fontes e as interpretações ou entre as interpretações e os problemas contemporâneos, as ideologias e os interesses políticos ou teóricos imediatos" (2001, p. 15-6).

${ }^{4}$ Antonio Gramsci classificou de fontes indiretas as utopias e os chamados romances filosóficos. Todavia, suas notas já revelam que as referidas obras também poderiam assumir a condição de fontes diretas, ou seja, tudo depende da forma de estudo das obras e dos objetivos a alcançar. (2002b, p. 142-43).

${ }^{5}$ A obra de José Antonio Pimenta Bueno, aqui citada, foi publicada pela primeira vez em 1857, tendo como título: Direito público Brasileiro e análise da Constituição do Império. Montesquieu já chamava a atenção para os necessários cuidados no processo de aprovação das leis. Segundo ele, as leis devem ser "tão adequadas ao povo para o qual foram feitas, que somente por um grande acaso, as leis de uma nação podem convir a outra" $(1979$, p. 28$)$.

${ }^{6}$ Ao utilizar a expressão "felicidade de todos e de cada um", Pimenta Bueno, possivelmente, reportou-se ao filósofo e jurista inglês Jeremy Bentham, pois era um dos seus leitores. Bentham sustentava que os homens e a sociedade eram governados por dois senhores: a dor e prazer. "Ao trono desses dois senhores está vinculada, por uma parte, a norma que distingue o que é reto do que é errado, e, por outra, a cadeia das causas e dos efeitos". A partir do conceito de dor e prazer defendeu o principio da utilidade nas ações dos indivíduos e do Estado. Dizia ele: "reconhece esta sujeição e a coloca como fundamento desse sistema, cujo objetivo consiste em construir o edifício da felicidade através da razão e da lei". (BENTHAM, 1979, p. 3).

${ }^{7}$ Conforme constatou Antonio Gramsci, o "direito não exprime toda a sociedade", pois, nem todos os indivíduos têm seus direitos assegurados, seja por falha jurídica, características culturais, relapsos individuais, etc. Mas, mesmo assim, ele não é uma "retórica vazia", pois, ao menos legitima o poder da classe dirigente. Esta, por sua vez, procura impor a "toda a sociedade aquelas normas de conduta que estão mais ligadas à sua razão de ser e ao seu desenvolvimento", do que ao conjunto social. No entendimento de Gramsci, a retórica máxima do direito, difundida pelas elites, é: "pressupor que todos os cidadãos devem aceitar livremente o conformismo assinalado pelo direito, de vez que todos podem se tornar elementos da classe dirigente". Gramsci conclui que, na concepção de direito moderno propagado pelas classes dirigentes, "está implícita a utopia democrática do século XVIII" (GRAMSCI, 2002a, p. 249).

${ }^{8}$ Em outra nota, Gramsci acrescentou: "todo o Estado é ético na medida em que uma de suas funções mais importantes é elevar a grande massa da população a um determinado nível cultural e moral, nível (ou tipo) que corresponde às necessidades de desenvolvimento das forças produtivas e, portanto, aos interesses das classes dominantes. A escola como função educativa positiva e os tribunais como função educativa 
repressiva e negativa são as atividades estatais mais importantes neste sentido: mas, na realidade, para este fim tende uma multiplicidade de outras iniciativas e atividades chamadas privadas, que formam o aparelho da hegemonia política e cultural das classes dominantes" (Idem, p. 284).

${ }^{9}$ Paulino José soares de Sousa, um dos líderes do Partido Conservador no Império, definiu a ação estatal da seguinte forma: "Não se pode dar organização política sólida e duradoura sem centralização". E destacou o papel da estrutura administrativa no Estado Monárquico: “A administração é portanto a ação vital do poder político e o seu indispensável complemento. O poder político é a cabeça, a administração o braço. O poder político serve-se da administração para fazer prevalecer o seu sistema, e dar aos serviços públicos um impulso em harmonia com suas vistas" (Cf. URUGUAI, 2002, p. 90 e 91). Nem sempre um Estado forte e centralizado impõe o cumprimento da legislação. Sobre essa questão, Gramsci fez a seguinte afirmação: "Uma opinião muito difundida é esta: enquanto para os cidadãos a observância das leis é uma obrigação jurídica, para o 'Estado' a observância é só uma obrigação moral, isto é, uma obrigação sem sansões punitivas pelo descumprimento". (2002a, p. 258). A história já provou que o cumprimento efetivo das leis só ocorre quando há pressão da sociedade civil, o que não era uma condição no Império brasileiro.

${ }^{10}$ A consulta ao significado das palavras e expressões foi feita nos dicionários do século XIX, que fazem parte do acervo da Biblioteca Brasiliana da USP. Disponível em: http://www.brasiliana.usp.br/dicionario

${ }^{11}$ Montesquieu já enfatizava a importância dos diversos níveis da hierarquia administrativa para a execução das leis num governo monárquico. Segundo ele, "os poderes intermediários, subordinados e dependentes, constituem a natureza do governo monárquico, isto é, daquele em que uma só pessoa governa baseada em leis fundamentais. Dissemos os poderes intermediários, subordinados e dependentes; com efeito, na monarquia o príncipe é a fonte de todo o poder político e civil. Essas leis fundamentais supõem necessariamente canais médios por onde o poder se manifesta" (1979, p. 35).

${ }^{12}$ Marx, ao analisar o capitalismo inglês no século XIX concluiu que a legislação fabril foi a "primeira concessão penosamente arrancada do capital". Naquela oportunidade Marx já evidenciou o caráter dúbio da legislação: "Se a generalização da legislação fabril tornou-se inevitável como meio de proteção física e espiritual da classe operária, ela, por outro lado, generaliza e acelera, como já foi aventado, a metamorfose de processos de trabalho esparsos realizados em pequena escala em processos de trabalho combinados e em larga escala social, portanto a concentração do capital e o domínio exclusivo do regime de fábrica" (Cf. MARX, 1985, 90 e 100 respectivamente). Em outras palavras: se, por um lado, as conquistas legais possibilitaram ganhos ao operariado, por outro, permitiram o avanço do capitalismo e contribuíram para fragmentar os processos de trabalho.

13 Para Thompson, "a retórica e as regras de uma sociedade são muito mais que meras imposturas. Simultaneamente podem modificar em profundidade o comportamento dos poderosos e mistificar os destituídos do poder. Podem disfarçar as verdadeiras realidades do poder, mas ao mesmo tempo podem refrear esse poder e conter seus excessos" (Idem, p. 356).

${ }^{14}$ Segundo Gramsci, “O que se chama de ‘opinião pública’ está estritamente ligado à hegemonia política, ou seja, é o ponto de contato entre a 'sociedade civil' e a 'sociedade política', entre o consenso e a força. O Estado, quando quer iniciar uma ação pouco popular, cria preventivamente a opinião pública adequada, ou seja, organiza e centraliza certos elementos da sociedade civil" (2002a, p. 265). Em outras palavras: a hegemonia política exercida por um determinado grupo ou classe social é resultado de um enfrentamento político datado historicamente. Para Thompson, o conceito de hegemonia é muito valioso, pois sem ele fica difícil compreender como as relações sociais eram e são estruturadas. Entretanto, adverte-nos sobre o uso inadequado e exagerado do conceito, pois, segundo ele, mesmo quando a hegemonia é "imposta com sucesso, não impõe uma visão abrangente da vida. Ao contrário, ela impõe antolhos que impedem a visão em certas direções, embora a deixe livre em outras. [...]. Por isso, não posso aceitar a visão, popular em alguns círculos estruturalistas e marxistas na Europa Ocidental, de que a hegemonia impõe uma dominação abrangente aos governados - ou a todos que não são intelectuais - chegando até o próprio limiar de sua experiência, e implantando em suas mentes, no momento do nascimento, as categorias de subordinação, das quais eles são incapazes de se livrar e que sua experiência não é capaz de corrigir” (1998, p. 79).

${ }^{15}$ Para compreender o papel do parlamento no debate sobre a educação no Brasil, Cf. (SAVIANI, 1996).

${ }^{16}$ Tavares Bastos definiu o poder dos presidentes das províncias no Império da seguinte forma: "O presidente exerce hoje uma dupla autoridade: delegado do governo central, administra e inspeciona os negócios gerais na província; executor das resoluções da assembleia, dirige e promove os interesses peculiares da província. Confundidas atualmente nas mãos de um só funcionário, essas duas fontes de poder conspiram para convertêlo em um verdadeiro vice-rei” (1975, p. 89).

${ }^{17}$ Uma observação feita por Gramsci sobre a execução das leis explica, de certa forma, as condições do 
Brasil imperial. Segundo ele, “em certos países as constituições são modificadas pelas leis, as leis pelos regulamentos e o texto dos regulamentos por sua aplicação. Quem executa a 'lei' (o regulamento) é recrutado num certo estrato social, de um certo nível de cultura, selecionado através de um certo salário, etc. A lei é este executor, é o modo como se executa, especialmente porque não existem órgãos de controle e de opinião" (2001, p. 128). No império, a maioria dos ocupantes dos cargos de inspetores gerais na Corte e nas províncias eram formados em direito e muitos deles eram políticos. A história mostra que a eficiência e/ou ineficiência da legislação educacional dependeu muito do compromisso político de quem ocupou o cargo de inspetor de instrução pública.

${ }^{18}$ Cf. CASTANHA, André Paulo. O Ato Adicional e a instrução elementar no Império: descentralização ou centralização? São Carlos-SP: UFSCar, 2007. (Tese de doutorado). Especialmente o primeiro capítulo. Ao se reportar ao problema da instabilidade na administração, Paulino José Soares de Sousa fez a seguinte afirmação: "Nos países que não possuem instituições semelhantes, completa e praticamente desenvolvidas, cada mudança de ministério e de administradores, como são os nossos presidentes, traz uma inversão e às vezes completa não só no pessoal administrativo, como no modo de encarar e decidir as questões administrativas. $\mathrm{O}$ administrador que começava a tomar pé nos negócios da província é mudado, leva consigo o que a custo aprendeu, e aí vem outro, o qual, apenas concluídas as primeiras apalpadelas, é também mudado. Et sic de coeteris (o mesmo sucede com os outros). É assim que somos administradores! A cada mudança tudo fica suspenso, posto em dúvida, para começar a ser examinado de novo, com grande desânimo, desespero e prejuízo das partes. Assim todos os grandes interesses a cargo da administração estão sujeitos a uma constante instabilidade, e a administração torna-se como tem sido entre nós, uma verdadeira teia de Penélope" (Cf. URUGUAI, 2002, p. 93-4). No Império houve um grande paradoxo na estrutura administrativa, envolvendo o primeiro e segundo escalões, no que se refere à instrução pública. Enquanto, no cargo de Ministro do Império e presidentes de províncias, houve uma circulação constante entre os ocupantes, o mesmo não ocorre no cargo de inspetor geral da instrução pública, tanto na Corte, como nas províncias. Vários inspetores tiveram mandatos longos, de 8, 10, 12 e de até mais de 20 anos. Tal paradoxo foi abordado de forma inicial na tese e merecerá aprofundamento em pesquisas futuras. Muitos desses inspetores se mostraram efetivamente comprometidos com a causa educacional, e boa parte do progresso da instrução no período deve ser atribuído mais a eles do que aos ministros e presidentes de províncias.

${ }^{19}$ No Brasil imperial, a Igreja Católica estava atrelada ao Estado, todavia, o poder da igreja não foi utilizado como instrumento para difundir a instrução pública, como ocorreu nos países de predomínio protestante. Enquanto, os protestantes consideravam um compromisso moral dos pais instruir seus filhos, possibilitandolhes a leitura da Bíblia, os católicos não se preocuparam com tal questão, pois a transmissão dos ensinamentos bíblicos era uma atribuição dos padres. Muitos padres exerceram a função de professor e de inspetores paroquiais e gerais. Além disso, o conteúdo religioso era obrigatório nas escolas primárias, mas tais fatores não representaram avanços no processo de escolarização.

${ }^{20}$ Em nota sobre os costumes e as leis Gramsci fez a seguinte afirmação: "É opinião muito difundida, ou melhor, é opinião considerada realista e inteligente que as leis devem ser antecedidas pelo costume, que a lei só é eficaz quando ratifica os costumes. Esta opinião está contra a história real do desenvolvimento do direito, que sempre exigiu uma luta para se afirmar, luta que, na realidade, é pela criação de um novo costume. Na opinião mencionada existe um resíduo muito evidente de moralismo intrometido na política" (2002a, p. 248).

${ }^{21}$ Segundo Montesquieu, as leis possuem "relações entre si e com sua origem, com os desígnios do legislador e com a ordem das coisas sobre as quais são elas estabelecidas. É preciso considerá-las em todos os seus aspectos" (1979, p. 28).

${ }^{22}$ A primeira edição desta obra ocorreu em 1858.

Recebido em: $\quad 19 / 01 / 11$

Aprovado em: $10 / 02 / 11$ 